\title{
Mateusz Kosmol
}

Uniwersytet Gdański

m.kosmol@prawo.ug.edu.pl

ORCID: https://orcid.org/0000-0002-4620-2404

\section{Laesio enormis w XXI w. - czy matematyczne podejście do ustalania granic dopuszczalnej nieekwiwalentności świadczeń w umowach dwustronnie zobowiązujących jest pożądane?}

http://dx.doi.org/10.12775/SIT.2019.023

Pytanie, czy istnieją - lub powinny istnieć - reguły określające relację wartości każdego ze wzajemnych świadczeń w zobowiązaniu dwustronnie zobowiązującym, postawił już Arystoteles. Rozważania tego wybitnego starożytnego filozofa koncentrowały się na idei sprawiedliwości wymiennej i związanego $z$ nią pojęcia słusznej ceny ${ }^{1}$. Także w Starym Testamencie jest mowa o zakazie wyzyskiwania jednych przez drugich ${ }^{2}$. Zabronione było stosowanie lichwy, która biedniejszych rolników szybko mogłaby doprowadzić na skraj nędzy.

${ }^{1}$ Arystoteles, Etyka Nikomachejska, 1132b przywoływany w: W. Dajczak, T. Giaro, F. Longchamps de Berier, Prawo rzymskie u podstaw prawa prywatnego, Warszawa 2009, s. 468.

${ }^{2}$ Por. przykładowo Ez 18, 8-9. 
Rozważania nad ekonomiczną słusznością umowy i jej ważnością na szerszą skalę prowadzono w starożytnym Rzymie ${ }^{3}$. W okresie przedklasycznym i klasycznym juryści rzymscy dopuszczali praktycznie dowolne kształtowanie cen przez kontrahentów ${ }^{4}$. Jako ograniczenie swobody kontraktowej wskazywano jednakże umyślne wprowadzanie w błąd (dolus) lub wykorzystanie przymusowego położenia drugiej strony (metus) ${ }^{5}$. Wyjątek od utrwalonego stanowiska w kwestii dowolności ustalania przez strony relacji świadczeń wzajemnych ustanowił cesarz Dioklecjan. Wprowadził tzw. ochronę przed nadmiernym uszczerbkiem, a konstrukcja ta odnosiła się do sprzedaży nieruchomości. Jeżeli zastrzeżona cena była co najmniej o połowę niższa od ceny rzeczywistej (verum pretium), sprzedawca miał prawo do odstąpienia od umowy, jeśli tylko kupujący nie wyrównał zaniżonej ceny ${ }^{6}$. Takie podejście upowszechniło się wraz z upływem czasu i zostało rozszerzone także na inne typy umów ${ }^{7}$.

W średniowieczu ukształtowała się natomiast instytucja laesio enormis. Rozwiązanie to wzorowane było na idei słusznościowej, obowiązującej już w imperium rzymskim. Za punkt odniesienia do badania ekwiwalentności świadczeń przyjmowano cenę rynkową Problematyka ta powróciła przy tworzeniu nowożytnych kodyfikacji europejskich ${ }^{9}$. W Niemczech przeważyło liberalne stanowisko, zgodnie $z$ którym niewskazane jest zbyt daleko idące ograniczanie autonomii woli podmiotów prawa cywilnego. Odpowiednik laesio enormis nie występuje więc w porządku prawnym tego państwa,

${ }^{3}$ W. Dajczak, The Polish way to a unified law of contract - local curiosity or contribution to the European debate today, w: Deutschland und Polen in der europäischen Rechtsgemeinschaft, red. Ch. Bar, A. Wudarski, München 2012, s. 16.

${ }^{4} \mathrm{~J}$. Andrzejewski, Laesio enormis i wyzysk. Tradycja prawna a przeciwdziałanie nieekwiwalentności świadczeń $w$ prawie prywatnym Austrii, Niemiec i Polski, rozprawa doktorska, s. 17, https://repozytorium.amu.edu.pl/bitstream/10593/13070/1/LAESIO\%20ENORMIS\%20I\%20WYZYSK.J.A.DOKTORAT_2015-PDF.pdf (dostęp: 10.10.2019 r.).

${ }^{5}$ W. Dajczak, T. Giaro, F. Longchamps de Berier, Prawo rzymskie, s. 469.

${ }^{6}$ Ibidem, s. 491.

7 Ibidem, s. 469.

8 Ibidem, s. 492.

${ }^{9}$ W. Dajczak, The Polish way, s. 16. 
jednakże wprowadzono instytucję wyzysku (Wucher, § 138 ust. 2 niemieckiego kodeksu cywilnego ${ }^{10}$ ), zasadniczo podobną do regulacji polskiej (art. 388 kodeksu cywilnego; dalej: k.c.), a więc opartą także na przesłankach subiektywnych. Wzorowaną na prawie rzymskim ingerencję w ekwiwalentność świadczeń w ramach sprzedaży nieruchomości wprowadzono we Francji (art. 1674 francuskiego kodeksu cywilnego $^{11}$ ). Nie ma ona jednak większego znaczenia $z$ powodu jej ograniczonego zastosowania ${ }^{12}$. Instytucję laesio enormis w klasycznym znaczeniu tego pojęcia odnaleźć można natomiast w porządku prawnym Austrii (§ 934 oraz § 935 austriackiego kodeksu cywilnego ${ }^{13}$; dalej: ABGB), co stanowi ewenement na skalę europejską. W związku $\mathrm{z}$ powyższym interesujące wydaje się przyjrzenie się tej instytucji i być może wyciągnięcie odpowiednich wniosków de lege ferenda dla naszego ustawodawcy.

\section{Laesio enormis w systemie prawa austriackiego}

\subsection{Wprowadzenie - podwójna ochrona przed nieekwiwalentnością świadczeń}

Austriackie prawo prywatne, w przeciwieństwie do prawa polskiego, zna aż dwie instytucje mające za zadanie zapobieganie nieekwiwalentności świadczeń w zobowiązaniach dwustronnie zobowiązujących: wynagrodzenie za pokrzywdzenie ponad połowę ${ }^{14}$ (Schadloshaltung

${ }^{10}$ Bürgerliches Gesetzbuch in der Fassung der Bekanntmachung vom 2. Januar 2002 (BGBl. I S. 42, 2909; 2003 I S. 738).

${ }^{11}$ Kodeks Napoleona - Code civil des Français z 1804 r. W. Dajczak, T. Giaro, F. Longchamps de Berier, Prawo rzymskie, s. 470.

12 Ibidem, s. 470.

13 Allgemeines bürgerliches Gesetzbuch für die gesammten deutschen Erbländer der Oesterreichischen Monarchie (JGS Nr. 946/1811).

${ }^{14} \mathrm{~W}$ moim odczuciu nie do końca jest jasne, jak niniejszą instytucję powinno tłumaczyć się na język polski. W omawianej sytuacji trudno mówić bowiem o „odszkodowaniu” czy „poszkodowaniu” w stricte prawnych znaczeniach tych słów w Polsce. W związku z tym będę używał zwrotów „wynagrodzenie” oraz 
wegen Verkürzung über die Hälfte; nazywane także krócej: laesio enormis ${ }^{15}$ ) oraz wyzysk (Wucher) ${ }^{16}$. Laesio enormis zostało uregulowane w § 934 oraz 935, natomiast wyzysk w $\S 879$ ust. 2 pkt 4 ABGB. W niniejszym artykule omówione zostanie jedynie laesio enormis, a rozważaniom nad wyzyskiem $z$ perspektywy prawa austriackiego poświęcę $\mathrm{w}$ przyszłości oddzielny tekst.

W myśl § 934 ABGB, „Gdy przy dwustronnie zobowiązującej czynności prawnej jedna ze stron nie otrzyma od drugiej strony połowy tego, co sama jej dała, biorąc pod uwagę zwyczajną wartość świadczeń, strona pokrzywdzona ma na mocy ustawy prawo do uchylenia zobowiązania i przywrócenia stanu poprzedniego. Druga strona jest jednak uprawniona do utrzymania zobowiązania w mocy poprzez zaofiarowanie stronie pokrzywdzonej wyrównania do zwyczajnej wartości świadczenia. Różnice wartości ustala się na moment zawarcia zobowiązania"17.

„pokrzywdzenie”, pomimo niepełnej precyzyjności semantycznej tak skonstruowanej wypowiedzi.

15 Por. przykładowo A. Vonkilch, Einführung in das Privatrecht, Wien 2017, s. 65.

${ }^{16}$ Por. A. Weilinger, Privatrecht. Eine Einführung, wyd. 5, Wien 2016, s. 77; S. Perner, M. Spitzer, G. Kodek, Bürgerliches Recht. Lernen. Üben. Wissen, wyd. 5, Wien 2016, s. 200; H. Koziol, R. Welser, A. Kletecka, Grundriss des bürgerlichen Rechts. Band I: Allgemeiner Teil, Sachenrecht, Familienrecht, Wien 2014, s. 106, 109; P. Bydlinski, Grundzüge des Privatrechts für Ausbildung und Praxis, Wien 2014, s. 156; red. P. Apathy, P. Bydlinski, S. Dullinger, B. Eccher, G. Iro, F. Kerschner, W. Posch, A. Riedler, Bürgerliches Recht. Band VIII: Prüfungstraining. Fallrepetitorium mit Lösungen, Wien 2010, s. 70 i nast.; J. Andrzejewski, Laesio enormis s. 43.

17 Tłumaczenie własne autora. Patrz też tłumaczenie ABGB z 1860 r. autorstwa W. Majera, w: Powszechna księga ustaw cywilnych dla wszystkich krajów dziedzicznych niemieckich monarchii austriackiej, red. F. Kasparek, M. Zatorski, Cieszyn 1894, www.pwsz.legnica.edu.pl/ siejam/ustawy/abgb (dostęp: 10.10.2019 r.):

„§ 934. Gdy w interesach obustronnie obowiązujących, strona jedna ze względu na zwyczajną wartość rzeczy nie dostaje ani połowy tego od drugiej, co jej dała; natenczas dozwala ustawa stronie uszkodzonej żądać zniesienia umowy i przywrócenia do dawnego stanu. Może jednak druga strona utrzymać w całości umowę, ofiarując dołożyć tyle, ile do zwyczajnej wartości brakuje. Niestosunkowość wartości oznacza się według czasu, w którym umowa zawartą została”. 


\subsection{Przesłanki zastosowania laesio enormis}

Przesłankami zastosowania omawianej instytucji i w konsekwencji uchylenia ${ }^{18}$ umowy są (wszystkie poniższe przesłanki muszą zostać spełnione łącznie):

1. wystąpienie dwustronnie zobowiązującej czynności prawnej;

2. świadczenie jednej strony warte jest mniej niż połowa wartości świadczenia drugiej strony;

3. nieekwiwalentność świadczeń w momencie zawarcia zobowiązania;

4. czynność prawna nie należy do wyjątków wyłączonych spod ochrony (określonych w § 935, 1268 oraz 1386 ABGB);

5. strona szkodząca nie ofiarowuje stronie pokrzywdzonej wyrównania do zwyczajnej wartości świadczenia ${ }^{19}$.

Ad 1. Czynność prawna dwustronnie zobowiązująca

ABGB wymaga w pierwszej kolejności, aby czynność prawna miała charakter czynności dwustronnie zobowiązującej (zweiseitig verbindliches Geschäft). Zobowiązanie ma być także odpłatne (entgentlich) ${ }^{20}, \mathrm{w}$ związku $\mathrm{z}$ czym w literaturze wskazuje się, że przy pomocy Verkürzung über die Hälfte nie jest możliwe podważenie umowy darowizny, natomiast nie ma normatywnych przeciwskazań, aby konstrukcję tę zastosować do umów zamiany, leasingu, najmu, ubezpieczenia czy sprzedaży ${ }^{21}$.

${ }^{18}$ W literaturze nie ma pełnej zgody co do charakteru Recht auf Aufhebung„prawa do uchylenia (zobowiązania)”, por. A. Weilinger, Privatrecht, s. 78.

19 A. Riedler, Zivilrecht I. Allgemeiner Teil, Wien 2015, s. 320-324.

${ }^{20}$ E. Hödl, Komentarz do $\$ 934$ ABGB, w: ABGB Taschenkommentar mit EheG, EPG, EKHG und KSchG, red. M. Schwimann, Wien 2015, nb. 1; orzeczenia Oberste Gerichtshof (austriackiego Sądu Najwyższego, dalej: OGH) z dnia 24 września 1969 r., 6 Ob 174/69, SZ 42/136; z dnia 20 stycznia 1972 r., $6 \mathrm{Ob} 328 / 71$, MietSlg 24097. Informacje dotyczące wybranych przeze mnie orzeczeń, ich publikatorów albo faktu ewentualnego nieopublikowania pochodzą z rządowej bazy Bundesministerium für Digitalisierung und Wirtschaftsstandort (Rechtsinformationssystem des Bundes) dostępnej pod adresem: https://www. ris.bka.gv.at/Jus/ (dostęp: 10.10.2019 r.).

${ }^{21}$ A. Riedler, Zivilrecht I, s. 321. 
Ad 2. Świadczenie jednej strony warte jest mniej niż połowa wartości świadczenia drugiej strony

Kolejnym warunkiem zastosowania omawianej instytucji jest wystąpienie rażącej nieekwiwalentności świadczeńn ${ }^{22}$. Ustawodawca austriacki matematycznie określił wymaganą dysproporcję, wskazując, że świadczenie jednej strony musi być warte mniej niż połowa wartości świadczenia drugiej strony. Oznacza to, że dysproporcja w wartości świadczeń musi wynosić więcej niż 50:100, a więc np. 49:100²3.

Jako punkt odniesienia należy przyjąć obiektywną, zwykłą wartość (gemeine Wert) świadczeń, a więc zasadniczo ich wartość rynkową (§ $305 \mathrm{ABGB})^{24}$.

Ad 3. Nieekwiwalentność świadczeń w momencie zawierania zobowiązania

Omówiona powyżej dysproporcja w wartości świadczeń wzajemnych musi występować w momencie zawierania zobowiązania ${ }^{25}$. Późniejsze zmiany wartości nie mogą już być brane pod uwagę, ponieważ austriacki kodeks cywilny wprost określa chwilę właściwą do oceny wartości świadczeń (§ 934 in fine ABGB $)^{26}$.

Warto wskazać w tym miejscu, że ABGB przewiduje również instytucję podobną do laesio enormis, pozwalającą na podważenie umowy zamiany (Tauschvertrag), kiedy przed wydaniem rzeczy, ale już po zawarciu umowy, wartość rzeczy zmieniła się

${ }^{22}$ E. Hödl, Komentarz do $\$ 934$ ABGB, nb. 2.

${ }^{23}$ M. Hofmair, Repetitorium aus Zivilrecht Allgemeiner Teil, s. 77, https:// zivilrecht.univie.ac.at/fileadmin/user_upload/i_zivilrecht/Schauer/RepAT_Willensmaengel.pdf (dostęp: 10.10.2019 r.).

${ }^{24}$ A. Riedler, Zivilrecht I, s. 321; orzeczenia OGH z dnia 05 października 1955 r., 2 Ob 438/55; EvBl 1956/232 s. 434; z dnia 12 kwietnia 1983 r., 4 Ob 536/83, RZ 1984/29 s. 95; z dnia 5 lipca 2011 r., 4 Ob 44/11s, SZ 2011/83.

25 S. Perner, M. Spitzer, G. Kodek, Bürgerliches Recht, s. 200; E. Hödl, Komentarz do $\$ 934$ ABGB, nb. 6; orzeczenie OGH z dnia 17 kwietnia 2007 r., 10 Ob. 21/07 x, niepubl.

${ }^{26}$ P. Bydlinski, Bürgerliches Recht Allgemeiner Teil. Bürgerliches Recht, Band I, Wien 2016, s. 214-215; S. Perner, Komentarz do art. 934 ABGB, w: ABGB Praxiskommentar. Band 4: §§ 859-1089 ABGB. WuchG, UN-Kaufrecht, red. M. Schwimann, G. Kodek, Wien 2014, nb. 8. 
o ponad połowę. W takiej sytuacji umowę zamiany uważa się za niezawartą (por. szerzej § 1048 ABGB). Analogiczna sytuacja dotyczy również umowy sprzedaży (§ 1064 ABGB). Omawianą instytucję nazywa się również „następczą” laesio enormis („Nachträgliche" laesio enormis) ${ }^{27}$.

Ad 4. Wyjątki wyłączone spod ochrony

Ustawodawca austriacki wyłączył konkretne sytuacje faktyczne spod ochrony objętej laesio enormis bezpośrednio w prawie pisanym. Główne wyjątki sprecyzowano w $§ 935$ ABGB i są nimi:

- kupujący nabył rzecz z powodu szczególnego upodobania (besondere Vorliebe);

- posiadanie przez pokrzywdzonego w momencie zawierania zobowiązania faktycznej wiedzy o różnicy w wartości świadczeń (Kenntnis von Wertmissverhältnis) ${ }^{28}$;

- występowanie mieszanej darowizny (gemischte Schenkung);

- niemożliwość ustalenia wartości świadczeń (mangelende Feststellbarkeit des Wertes);

- rzecz została sprzedana na aukcji sądowej (gerichtliche

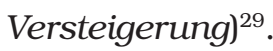

Natomiast z przepisów szczegółowych wynika, że za pomocą omawianej instytucji nie jest możliwe podważenie umowy losowej $^{30}$ (Glücksvertrag; § 1268 ABGB) oraz ugody (Vergleich; $\S 1386$ ABGB).

Powyższe wyłączenia uzasadnione są założeniem, że pokrzywdzony świadomie godzi się na zawarcie zobowiązania o danej

${ }^{27}$ Por. szerzej Ch. Bezemek, Die Geschäftsgrundlage im österreichischen Zivilrecht. Strukturfragen und Synopse, Wien 2010, s. 53 i nast., 97 i nast.

${ }^{28}$ Niewystarczające jest formalne stwierdzenie, np. w ogólnych warunkach umów, że zna się wartość świadczenia, por. E. Hödl, Komentarz do § 935 ABGB, nb. 6; orzeczenia OGH z dnia 30 sierpnia 1995 r., 3 Ob 520/94, SZ 68/152; z dnia 30 marca 2016 r., 6 Ob 20/16h, niepubl.

29 Stąd wyjątek nie obejmuje aukcji innego typu, jak np. internetowych, por. orzeczenie OGH z dnia 7 sierpnia 2007 r., 4 Ob 135/07 t, SZ 2007/121.

30 Nic nie stoi jednak na przeszkodzie, aby umowę taką podważyć na podstawie wyzysku, por. orzeczenie OGH z dnia 13 lipca 1994 r., 3 Ob 503/93, SZ 67/123. 
treści albo powinien liczyć się z podwyższonym ryzykiem danej transakcji ${ }^{31}$.

Z orzecznictwa wynika ponadto brak możliwości wykorzystania Verkürzung über die Hälfte do podważania zrzeczenia się praw w ramach stosunku najmu (Verzicht auf Mietrechte) ${ }^{32}$. Zastosowanie przepisu $\S 934$ ABGB będzie także niemożliwe w ramach odpłatnej umowy o dokonanie czynności duchowej (spirituelle Handlung) ${ }^{33}$ czy w przypadku zakupu akcji ${ }^{34}$.

Wątpliwości dotyczą natomiast umów sprzedaży dzieł sztuki, ponieważ zazwyczaj ich wartość kształtuje się na podstawie szczególnych upodobań nabywców. Jednakże gdy występuje możliwość wyceny dzieła artystycznego $z$ powodu chociażby ukształtowania się jego wartości na rynku, możliwe jest również podważenie umowy (np. w przypadku świętej figurki Gotów) ${ }^{35}$. Nie będzie to dotyczyło natomiast pierwszego nabycia dzieła sztuki bezpośrednio od jego twórcy (za cenę wynikającą ze szczególnego upodobania nabywcy) $)^{36}$ ani też zakupu bardzo rzadkich dzieł sztuki ${ }^{37}$.

Ad 5. Brak zaoferowania przez stronę szkodzącą wyrównania do zwyczajnej wartości świadczenia

Gdy osoba pokrzywdzona zamierza skorzystać z ochrony, jaką daje jej laesio enormis, a może być to dowolna strona zobowiązania, druga strona może uniknąć uchylenia czynności prawnej poprzez zaofiarowanie wyrównania do zwyczajnej wartości

${ }^{31}$ S. Perner, M. Spitzer, G. Kodek, Bürgerliches Recht, s. 201.

${ }^{32}$ Ponieważ takie działanie powinno być rozpatrywane $z$ punktu widzenia ewentualnego naruszenia zasad współżycia społecznego, por. orzeczenie OGH z dnia 4 maja 1955 r., 1 Ob 235/55, JBl 1955,473.

${ }^{33}$ Orzeczenie OGH z dnia 13 kwietnia 2000 r., 6 Ob 187/99i, niepubl. (tutaj wtajemniczenie/mianowanie na Mistrza Reiki).

${ }^{34}$ Orzeczenie OGH z dnia 5 lipca 2011 r., 4 Ob 44/11s, SZ 2011/83.

35 S. Perner, Komentarz do art. 934 ABGB, w: nb. 8; orzeczenia OGH z dnia 15 listopada 1961 r., 1 Ob 453/61, RZ 1962,83; z dnia 30 listopada 1966 r., 6 Ob 342/66, niepubl.; 26 września 2017 r., 4 Ob 64/17s, niepubl.

${ }^{36}$ Orzeczenie OGH z dnia 30 listopada 1966 r., 6 Ob 342/66, JBl 1967,620.

37 Orzeczenie Reichsgericht (Sądu Rzeszy) z dnia 30 listopada 1942 r., DREvBl 1943/87, przywoływane w orzeczeniu OGH z dnia 30 listopada 1966 r., 6 Ob 342/66, JBl 1967,620. 
świadczenia (facultas alternativa) ${ }^{38} . Z$ uprawnienia tego może skorzystać do końca ustnej rozprawy w I instancji ${ }^{39}$, w następstwie czego zostanie wydany wyrok nakazujący zapłatę odpowiednej sumy pieniężnej ${ }^{40}$.

\subsection{Uwagi szczegółowe}

Instytucja laesio enormis ma charakter bezwzględnie obowiązujący (§ $935 a b$ initio $\mathrm{ABGB}{ }^{41}$. Można jednak wyłączyć ją na niekorzyść przedsiębiorcy (§ 351 austriackiego kodeksu przedsiębiorców) ${ }^{42}$. W literaturze wskazuje się natomiast, że dozwolone jest zrzeczenie się skorzystania $z$ uprawnienia już po jego powstaniu ${ }^{43}$.

Na Verkürzung über die Hälfte można powołać się jeszcze przed wykonaniem zobowiązania ${ }^{44}$.

Z orzecznictwa wynika, że możliwe jest zastosowanie przedmiotowej konstrukcji również do podważenia umowy przedwstępnej (Vorvertrag) $^{45}$ czy umowy sprzedaży używanego pojazdu ${ }^{46}$. Analo-

38 P. Bydlinski, Grundzüge des Privatrecht, s. 155; S. Perner, M. Spitzer, G. Kodek, Bürgerliches Recht, s. 200; E. Hödl, Komentarz do § 934 ABGB, nb. 13; W. Zankl, Bürgerliches Recht, Wien 2017, s. 117-118.

$39 \mathrm{~S}$. Perner, Komentarz do art. 934 ABGB, nb. 22; orzeczenie OGH z dnia 30 sierpnia 1995 r., 3 Ob 520/94, SZ 68/152; z dnia 13 listopada 2002 r., 7 Ob 251/02s, niepubl.

${ }^{40}$ A. Riedler, Zivilrecht I, s. 323; orzeczenie OGH z dnia 25 lutego 1993 r., 6 Ob 618/92, RdW 1943,274.

${ }^{41}$ S. Perner, Komentarz do art. 935 ABGB, nb. 1.

${ }^{42}$ Bundesgesetz über besondere zivilrechtliche Vorschriften für Unternehmen (Unternehmensgesetzbuch - UGB), dRGB1. S 219/1897; P. Bydlinski, Grundzüge des Privatrechts, s. 155; S. Perner, M. Spitzer, G. Kodek, Bürgerliches Recht, s. 201; E. Hödl, Komentarz do § 935 ABGB, nb. 1; S. Perner, Komentarz do art. 935 ABGB, nb. 1; W. Zankl, Bürgerliches Recht, s. 118.

${ }^{43}$ A. Riedler, Zivilrecht I, s. 325.

44 Orzeczenia OGH z dnia 4 marca 1924 r., 2 Ob 135/24, SZ 6/89; z dnia 6 czerwca 1990 r., 2 Ob 563/90, niepubl.

45 Orzeczenia OGH z dnia 24 września 1969 r., 6 Ob 174/69, SZ 42/136; z dnia 26 czerwca 1984 r., 2 Ob 579/84, RZ 1985/40 S 111.

46 T. Gschaar, Autokauf. Wichtige und nützliche Tipps, Arbeiterkammer Vorarlberg 2017, s. 22-23, https://vbg.arbeiterkammer.at/service/broschuere- 
giczna sytuacja dotyczy umowy dożywocia (Leibrentevertrag), gdy już w momencie zawierania umowy jest oczywiste, że $z$ powodu swojego zaawansowanego wieku dożywotnik nie otrzyma połowy tego, co sam przekazał drugiej stronie stosunku zobowiązaniowego ${ }^{47}$.

Umowy kreujące zobowiązanie o charakterze ciągłym (Dauerschuldverhältnisse) także można rozpatrywać pod kątem nadmiernej różnicy wartości świadczeń wzajemnych. Judykatura austriacka potwierdziła powyższe m.in. w ramach umów spółek (Gesellschaftsvertrag $)^{48}$ oraz umów najmu i dzierżawy, niezależnie od okoliczności, czy stosunek umowny nadal istnieje ${ }^{49}$.

Problematyczna i różnie postrzegana jest kwestia wzajemnego stosunku laesio enormis i uprawnień wynikających z rękojmi (Gewährleistung) ${ }^{50}$.

Realizacja prawa podmiotowego wynikającego z omawianej instytucji powinna nastąpić na drodze sądowej poprzez złożenie pozwu (Klage) albo zarzutu (Einrede) ${ }^{51}$. Zgodnie $z$ powszechnie przyjętym rozkładem ciężaru dowodu spoczywa on na pokrzywdzonym, natomiast gdy strona krzywdząca chce stwierdzić, że zastosowanie omawianej konstrukcji prawnej jest wyłączone, powinna podjąć działania zmierzające w tym celu ${ }^{52}$.

nundratgeber/Konsument/BRO_Autokauf_2017.pdf (dostęp: 10.10.2019 r.), orzeczenie OGH z dnia 17 kwietnia 2007 r., 100b21/07x, AnwBl 2008,58.

${ }^{47}$ P. Apathy, A. Riedler, Bürgerliches Recht. Band III. Schuldrecht Besonderer Teil, Wien 2010, s. 143 oraz przywoływane tam trzy linie orzecznicze odmiennie kształtujące podejście do maksymalnego okresu życia człowieka.

48 Orzeczenie OGH z dnia 21 września 1976 r., 1 Ob 708/76, GesRZ 1977,23.

49 Orzeczenie OGH z dnia 8 października 1935 r., 1 Ob 498/35, SZ 17/134.

${ }^{50}$ Zob. E. Hödl, Komentarz do § 934 ABGB, w: nb. 7; P. Bydlinski, Komentarz do $\$ 934$ ABGB, w: Kurzkommentar zum ABGB. Allgemeines bürgerliches Gesetzbuch, Ehegesetz, Konsumentenschutzgesetz, IPR-Gesetz, Rom I- und Rom II-VO, red. H. Koziol, P. Bydlinski, R. Bollenberger, Wien 2010, nb. 6; S. Dullinger, Bürgerliches Recht. Band II. Schuldrecht Allgemeiner Teil, Wien 2010, s. 85 i przywoływana tam literatura; orzeczenie OGH z dnia 17 kwietnia 2007 r., 100b21/07x, AnwB1 2008,58.

${ }^{51}$ Orzeczenie OGH z dnia 08 października 1935 r., 1 Ob 498/35, SZ 17/134; A. Riedler, Zivilrecht I, s. 325; E. Hödl, Komentarz do $\S 934$ ABGB, nb. 8; S. Perner, Komentarz do art. 934 ABGB, nb. 14.

52 Orzeczenia OGH z dnia 17 kwietnia 1997 r., sygn. akt 8 Ob 2177/96 x, niepubl.; z dnia 20 grudnia 2017 r., 8 Ob 126/17p, niepubl. 
Zastosowanie Verkürzung über die Hälfte powoduje uchylenie zobowiązania $\mathrm{z}$ mocą wsteczną (ex tunc) zarówno w aspekcie prawnozobowiązaniowym, jak i prawnorzeczowym ${ }^{53}$, co uprawnia do żądania zwrotu świadczeń.

Uprawnienie przedawnia się po upływie trzech lat od momentu zawarcia zobowiązania (§ $1487 \mathrm{ABGB})^{54}$.

\section{Wnioski dla polskiego ustawodawcy}

W Polsce brakuje rozwiązania analogicznego do przyjętego przez austriackiego ustawodawcę. Remedium na nieekwiwalentność świadczeń została przewidziana (jedynie) w art. 388 k.c., który wymaga jednak zaistnienia przesłanki obiektywnej i przesłanek subiektywnych $^{55}$. W sytuacjach krańcowo wyjątkowych lub przy niespełnieniu przesłanek wyzysku niewykluczone jest skorzystanie $z$ art. $58 \S 2$ k.c. i wniesienie do sądu pozwu o ustalenie bezwzględnej nieważności czynności prawnej, de lege lata jest to jednak kwestia sporna i problematyczna ${ }^{56}$. W ramach ochrony słabszej strony

${ }^{53}$ P. Bydlinski, Grundzüge des Privatrechts, s. 156; P. Bydlinski, Bürgerliches Recht, s. 213; S. Perner, M. Spitzer, G. Kodek, Bürgerliches Recht, s. 201; S. Perner, Komentarz do art. 934 ABGB, nb. 17; odmienny pogląd: por. przykładowo W. Zankl, Bürgerliches Recht, s. 118.

${ }^{54}$ P. Bydlinski, Bürgerliches Recht, s. 214; S. Perner, M. Spitzer, G. Kodek, Bürgerliches Recht, s. 200; E. Hödl, Komentarz do § 934 ABGB, nb. 12; W. Zankl, Bürgerliches Recht, s. 118.

55 Albo przesłanki subiektywnej, w zależności od wykładni przedmiotowego przepisu. Cześć doktryny wskazuje, że zastosowanie wyzysku uwarunkowane jest spełnieniem dwóch, z kolei inni autorzy podkreślają konieczność badania trzech przesłanek. Powyższe nie ma jednak znaczenia praktycznego, a przedmiotowa różnica wykazuje stricte konstrukcyjny, a nie merytoryczny charakter (por. M. Gutowski, Komentarz do art. 388 k.c., w: Kodeks cywilny. Tom II: Komentarz. Art. 353-626, red. M. Gutowski, Warszawa 2019, Legalis, pkt I 2 i przywoływana tam literatura).

56 Tematyka ta jest niezmiernie problematyczna. Skoro bowiem wyzysk jest immanentnie sprzeczny $z$ zasadami współżycia społecznego, a art. 388 k.c. wydaje się odgrywać rolę lex specialis w stosunku do art. 58 § 2 k.c., to stosowanie tego drugiego przepisu w sytuacjach objętych normatywnym zakresem wyzysku powinno być całkowicie wyłączone. W doktrynie i orzecznictwie za- 
umowy pomiędzy prawem polskim a prawem austriackim występują w związku z powyższym znaczne rozbieżności. Największe różnice zauważyć można między polską konstrukcją wyzysku a instytucją laesio enormis rozwiniętą przez prawo i orzecznictwo austriackie. Przede wszystkim leasio enormis ma tylko obiektywną i matematycznie określoną przesłankę dotyczącą nieekwiwalentności świadczeń, natomiast polski wyzysk charakteryzuje się, obok przesłanek obiektywnych, również dodatkowymi i trudnymi do udowodnienia przesłankami subiektywnymi. Oznacza to, że w Polsce ochrona pokrzywdzonych jest zdecydowanie mniej rozwinięta niż w Austrii. Dwuletni termin zawity ${ }^{57}$ na gruncie art. $388 \S 2$ k.c. jest również znacznie krótszy niż analogiczny, aż trzyletni, okres przyznany pokrzywdzonym w Austrii, który w dodatku jest przedawnieniem. Na podkreślenie zasługuje także dwutorowość ochrony przewidziana w tym kraju, zarówno pod względem omawianej konstrukcji, jak i słabszej, analogicznej do systemu niemieckiego oraz polskiego, koncepcji wyzysku.

Podsumowując rozważania wokół problemu nieekwiwalentności świadczeń i dopuszczalnej granicy swobody kontaktowej w tym zakresie, należałoby jednak nie tyle zastanowić się nad różnicami pomiędzy regulacjami prawnymi $\mathrm{w}$ obydwu państwach, ile postarać się udzielić odpowiedzi na pytanie, czy zasadne jest formułowanie wniosków de lege ferenda dla polskiego ustawodawcy.

uważa się jednak, że nie jest to nakaz absolutny, a np. przy niespełnieniu przesłanek wyzysku niewykluczone jest uznanie umowy za bezwzględnie nieważną na podstawie art. 58 § 2 k.c. (por. przykładowo P. Machnikowski, w: System prawa prywatnego, Tom 5: Prawo zobowiazań - część ogólna, red. K. Osajda, Warszawa 2019, s. 634-635 i przywoływana tam literatura i orzecznictwo (autor zdecydowanie krytykuje jednak „pochopne” stosowanie art. 58 § 2 k.c., które według niego można zaobserwować w orzecznictwie, podkreślając, że sama dysproporcja świadczeń nie powinna uzasadniać uznania umowy za nieważną); M. Gutowski, Komentarz do art. 388 k.c., w: Kodeks cywilny, red. M. Gutowski, pkt III 1-6 i przywoływana tam literatura i orzecznictwo (autor ten wyraźnie podkreśla konieczność wystąpienia szczególnych okoliczności, aby możliwe stało się sięgnięcie do art. 58 § 2 k.c.).

${ }^{57}$ P. Horosz, Komentarz do art. 388 k.c., w: Kodeks cywilny. Komentarz, red. M. Załucki, Warszawa 2019, Legalis, nb. 7. 
Teoretycznie może wydawać się, że odpowiedź na powyższe pytanie jest negatywna.

W pierwszej kolejności powinno się rozważyć kwestię natury ogólnej, mianowicie jak daleko powinien sięgać paternalizm państwa w ramach prawa kontraktów. W warunkach gospodarki rynkowej, w której popyt i podaż są dominującymi czynnikami kształtowania się cen, wydaje się, że prawo nie powinno stwarzać ponadprzeciętnej możliwości sądowej oceny ekwiwalentności świadczeń. Za wyrokiem Sądu Najwyższego z dnia 17 grudnia 1998 r. ${ }^{58}$ należałby raczej stwierdzić, że uzasadniona jest koncepcja, zgodnie z którą w imię stabilizacji stosunków ekonomicznych prawo powinno jak najszerszej chronić ważność umów. Zasadniczą wartością powinna być więc szeroka ochrona kontraktów, gdyż w znacznym stopniu wpływa to na pewność obrotu prawnego. Na niekorzyść konstrukcji laesio enormis przemawia fakt, że wprowadzenie tak daleko idącej ochrony zaburza naturalną potrzebę zdobywania informacji. W nowoczesnym społeczeństwie wolnorynkowym to informacja powinna stanowić istotne dobro, inkorporujące określoną wartość majątkową. Gdy ustawodawstwo przewiduje możliwość podważenia umowy z samego powodu nieekwiwalentności świadczeń wzajemnych, a w praktyce najczęściej z powodu zapłaty wysokiej ceny za nabywany produkt, nabywca nie musi już nawet wykazywać staranności w ramach badania wartości nabywanych rzeczy. Możliwe staje się wówczas kupno przedmiotu po kilkakrotnie wyższej cenie niż panująca na danym rynku przeciętna cena zbliżonej rzeczy, a po kilku latach (w Austrii aż do upływu trzech lat od dnia zawarcia umowy) sądowe podważenie umowy $z$ tego powodu. To nabywca powinien przecież wykazać staranność w zbadaniu danego rynku przed zakupem konkretnego dobra. Należy zauważyć, że na podmioty profesjonalnie zajmujące się sprzedażą nie powinno się nakładać zbytnich obciążeń prawnych, gdyż może to negatywnie wpłynąc na ich kondycję. W gospodarkach opartych na wolnym handlu zjawisko laesio enormis jest więc niepożądane, ponieważ nie sprzyja swobodzie kontraktowej. Ekonomiczna analiza prawa

58 Wyrok SN z dnia 17 grudnia 1998 r., II CKN 849/98, OSNC 1999, nr 7-8, poz. 128. 
także nie przemawia za rozwiązaniami przyjętymi w Austrii. Nie można również uzasadnić wprowadzenia analogicznych metod do polskiego ustawodawstwa ochroną konsumentów. Tak daleko idąca ochrona, z jaką mamy do czynienia w Austrii, nie ma bowiem na gruncie polskim uzasadnienia aksjologicznego.

Jednakże należy zauważyć, że w Polsce ochrona przyznawana podmiotowi słabszemu przez instytucję wyzysku jest zdecydowanie niewystarczająca, gdyż to na nim spoczywa obowiązek udowodnienia wszystkich okoliczności, na które się powołuje. W szczególności problematyczne jest wykazywanie zaistnienia subiektywnych przesłanek przewidzianych w ustawie. Prowadzi to do sytuacji, w której osoby pokrzywdzone często są pozbawione normatywnej możliwości podważenia niemoralnej umowy. Jest to więc sytuacja nie do zaakceptowania.

Na podstawie powyższych rozważań można wyciągnąć wniosek, zgodnie $\mathrm{z}$ którym instytucja wyzysku w polskim systemie prawnym powinna ulec zmianie. Jeżeli do modyfikacji nie dojdzie, nie będzie można mówić o efektywnej ochronie podmiotów faktycznie wyzyskiwanych, gdyż na aktualnym gruncie prawnym ciężar dowodu praktycznie uniemożliwia realną ochronę interesów tych osób. Reforma powinna jednak zostać przeprowadzona racjonalnie.

Nie jest jednakże zalecane wprowadzenie zmian w polskim prawie cywilnym na kształt austriackiej instytucji laesio enormis. Taka adaptacja byłyby nieadekwatna do realnych potrzeb społecznych. Niepożądane jest bowiem stworzenie sytuacji umożliwiającej aż przez trzy lata unieważnienie umowy $\mathrm{z}$ samego tylko powodu przekroczenia pewnego, matematycznie określonego pułapu nieekwiwalentności świadczeń. Tak sztywna i daleko idąca ochrona podmiotu słabszego jest na gruncie polskim nieuzasadniona. W moim przekonaniu laesio enormis może natomiast stanowić dla polskich sądów dobry punkt odniesienia w przypadku wątpliwości, czy doszło (już) do rażącej dysproporcji świadczeń w ramach wyzysku. Wydaje się bowiem, że co do zasady różnica wynosząca więcej niż połowę powinna być wystarczająca, aby uznać, że kryterium obiektywne zostało spełnione ${ }^{59}$.

${ }^{59}$ Wskazywał na to również F. Błahuta przywoływany w P. Machnikowski, w: System prawa prywatnego, s. 636 w przypisie; także Sąd Apelacyjny w Gdańsku (za sądem I instancji) w wyroku z dnia 19 kwietnia 2013 r., V ACa 171/13, 
Każda sprawa jest jednak inna, w związku z czym pod uwagę należy brać całokształt okoliczności faktycznych, a także stopień natężenia przesłanek subiektywnych.

\section{STRESZCZENIE}

Laesio enormis w XXI w. czy matematyczne podejście do ustalania granic dopuszczalnej nieekwiwalentności świadczeń w umowach dwustronnie zobowiązujących jest pożądane?

Niniejszy artykuł porusza problem (nie)ekwiwalentności świadczeń w zobowiązaniu dwustronnie zobowiązującym i jego konsekwencji. Przepisy prawa polskiego, w szczególności art. 388 kodeksu cywilnego, wydają się nie zaspokajać rzeczywistych potrzeb społecznych. W związku z tym konieczne jest głębsze spojrzenie na mechanizmy kontroli ekwiwalentności świadczeń. Interesujące wnioski wynikają $z$ analizy prawa i orzecznictwa austriackiego. Instytucja laesio enormis (Verkürzung über die Hälfte; § 934, 935 ABGB) może być pomocna przy formułowaniu wniosków de lege ferenda na polskim gruncie.

Słowa kluczowe: pokrzywdzenie ponad połowę; laesio enormis; wyzysk; nieekwiwalentność świadczeń; nieważność umowy; wzruszalność umowy

\section{SUMMARY}

Laesio enormis in the $21^{\text {st }}$ century is a mathematical approach to determining the limits of acceptable non-equivalence of benefits in bilaterally binding agreements desirable?

The article deals with the problem of (non)equivalence of performances in bilaterally binding agreement and consequences thereof. Our domes-

Legalis numer 736093, stwierdził, że o rażącej dysproporcji świadczeń można mówić, jeżeli cena sprzedaży (w tym wypadku nieruchomości) jest co najmniej dwukrotnie niższa niż rynkowa. 
tic regulations, in particular Art. 388 of the Polish Civil Code, currently seem to be insufficient for actual social needs. Therefore it is needed to look deeper into mechanisms for dealing with significant disproportion of benefits. Interesting light on this issue is being shed by Austrian statutory and case law. The institution of laesio enormis (Verkürzung über die Hälfte; § 934, 935 ABGB) may be helpful in formulating de lege ferenda proposals on the polish ground.

Keywords: reduction (of the amount) by the half; laesio enormis; exploitation; non-equivalence of benefits; nullity of a contract; voidability of a contract

\section{BIBLIOGRAFIA}

Andrzejewski J., Laesio enormis i wyzysk. Tradycja prawna a przeciwdziałanie nieekwiwalentności świadczeń $w$ prawie prywatnym Austrii, Niemiec i Polski, rozprawa doktorska, https://repozytorium.amu.edu.pl/ bitstream/10593/13070/1/LAESIO\%20ENORMIS\%20I\%20WYZYSK. J.A.DOKTORAT_2015-PDF.pdf (dostęp: 10.10.2019 r.).

Apathy P. (red.), Bürgerliches Recht. Band VIII. Prüfungstraining. Fallrepetitorium mit Lösungen, Wien 2010.

Apathy P., Riedler A., Bürgerliches Recht. Band III. Schuldrecht Besonderer Teil, Wien 2010.

Bezemek Ch., Die Geschäftsgrundlage im österreichischen Zivilrecht. Strukturfragen und Synopse, Wien 2010.

Bydlinski P., Bürgerliches Recht Allgemeiner Teil. Bürgerliches Recht, Band I, Wien 2016.

Bydlinski P., Grundzüge des Privatrechts für Ausbildung und Praxis, Wien 2014.

Bydlinski P., Komentarz do $\$ 934$ ABGB, w: Kurzkommentar zum ABGB. Allgemeines bürgerliches Gesetzbuch, Ehegesetz, Konsumentenschutzgesetz, IPR-Gesetz, Rom I- und Rom II-VO, red. H. Koziol, P. Bydlinski, R. Bollenberger, Wien 2010.

Dajczak W., Giaro T., Longchamps de Berier F., Prawo rzymskie u podstaw prawa prywatnego, Warszawa 2009.

Dajczak W., The Polish way to a unified law of contract - local curiosity or contribution to the European debate today, w: Deutschland und Polen in der europäischen Rechtsgemeinschaft, red. Ch. Bar, A. Wudarski, München 2012.

Dullinger S., Bürgerliches Recht. Band II. Schuldrecht Allgemeiner Teil, Wien 2010. 
Gutowski M., Komentarz do art. 388 k.c., w: Kodeks cywilny. Tom II: Komentarz. Art. 353-626, red. M. Gutowski, Warszawa 2019.

Hödl E., Komentarz do $\$ 934$ ABGB, w: ABGB Taschenkommentar mit EheG, EPG, EKHG und KSchG, red. M. Schwimann, Wien 2015.

Horosz P., Komentarz do art. 388 k.c., w: Kodeks cywilny. Komentarz, red. M. Załucki, Warszawa 2019.

Koziol H., Welser R., Kletecka A., Grundriss des bürgerlichen Rechts. Band I. Allgemeiner Teil, Sachenrecht, Familienrecht, Wien 2014.

Machnikowski P., w: System prawa prywatnego, Tom 5: Prawo zobowiazań - część ogólna, red. K. Osajda, Warszawa 2019.

Majer W., przekład ABGB, w: Powszechna ksiegga ustaw cywilnych dla wszystkich krajów dziedzicznych niemieckich monarchii austriackiej, red. F. Kasparek, M. Zatorski, Cieszyn 1894, www.pwsz.legnica.edu. $\mathrm{pl}$ / siejam/ustawy/abgb (dostęp: 10.10.2019 r.).

Perner S., Komentarz do art. 934 ABGB, w: ABGB Praxiskommentar. Band 4. §§ 859-1089 ABGB. WuchG, UN-Kaufrecht, red. M. Schwimann, G. Kodek, Wien 2014.

Perner S., Spitzer M., Kodek G., Bürgerliches Recht. Lernen. Üben. Wissen, Wien 2016.

Riedler A., Zivilrecht I. Allgemeiner Teil, Wien 2015.

Vonkilch A., Einführung in das Privatrecht, Wien 2017.

Weilinger A., Privatrecht. Eine Einführung, Wien 2016.

Zankl W., Bürgerliches Recht, Wien 2017. 
